CLINICAL HEMORHEOLOGY, Vol. 12, p.625, 1992

$0271-5198 / 92 \$ 5.00+.00$ Printed in the USA.

Copyright (c) 1992 Pergamon Press Ltd. All rights reserved.

\title{
ANNOUNCEMENT
}

\section{HEMORHEOLOGY IN THE NETHERLANDS}

A group of dutch (clinical) hemorheologists has recently joined the Benelux Society for Microcirculation. Those investigators working in the field of (clinical) hemorheology in the Benelux and who have not yet joined this hemorheological "section" of the Society, are kindly requested to contact:

Dr. Max R. Hardeman, dept. of Internal Medicine, Academic Medical Center, Meibergdreef 9,1105 AZ, Amsterdam, the Netherlands Tel: -31 205669111 (tracer \#468) ;Fax: -31 205664440 